\title{
Trends of Rainfall and Temperature in Bangladesh: A Comparative Analysis of CMIP 5 Results and Meteorological Station Data
}

\author{
Himel Bosu ${ }^{1}$, Towhida Rashid ${ }^{11}$ Abdul Mannan² and Javed Meandad ${ }^{1}$ \\ ${ }^{1}$ Department of Meteorology, University of Dhaka, Dhaka, Bangladesh \\ ${ }^{2}$ Bangladesh Meteorological Department, Dhaka, Bangladesh
}

Manuscript received: 26 November 2020; accepted for publication: 18 April 2021

\begin{abstract}
The Coupled Model Inter-comparison Project phase 5 (CMIP5) dataset along with rainfall and temperature data, recorded at 34 stations of Bangladesh Meteorological Department (BMD), is analyzed to examine the recent changes in rainfall and temperature over Bangladesh during the period 1981-2019. In the historical period, all three CMIP5 models (MPI-ESM-LR, MPI-ESM-MR and NorESM1-M) underestimated the observed mean rainfall data collected from BMD, whereas for temperature the result is found to be nearly similar between model and observation. The result shows a trend of increasing mean maximum temperature of Bangladesh at a rate of $0.19^{\circ} \mathrm{C}$ and $0.26^{\circ} \mathrm{C}$ per decade and increasing mean minimum temperature at a rate of $0.18^{\circ} \mathrm{C}$ and $0.15^{\circ} \mathrm{C}$ per decade, for model and observation respectively. The study found a decreasing trend of annual rainfall in Bangladesh observed at a rate of $41.60 \mathrm{~mm}$ and $39.77 \mathrm{~mm}$ per decade, respectively, for model and observation. Spatial distribution shows an increase in annual rainfall in the northeastern part of Bangladesh.
\end{abstract}

Keywords: Climate change, Rainfall, Temperature, Trends, CMIP5

\section{INTRODUCTION}

The study of global climate change has been ongoing for several decades already. The Intergovernmental Panel on Climate Change (IPCC) has termed Bangladesh as one of the most vulnerable countries in the world because of its climate change (IPCC, 2007). It has been predicted that because of climate change, there will be a gradual increase of temperature and change in rainfall pattern in Bangladesh which might have variety of implications in agriculture, water resources and public health (Karim et al., 1999; Fung et al., 2006; Shahid, 2009). The climate of Bangladesh is mostly tropical monsoon climate that is characterized by wide seasonal variations in rainfall with high temperatures and humidity. The three seasons are predominantly recognized as- i. Hot and muggy summer (March to June), ii. Hot and humid and rainy monsoon season (June to November), iii. Cold and dry winter (December to February). But from meteorological point of view, there are four seasons in Bangladesh. These are- i. Pre-monsoon (March to May), ii. Monsoon (June to September), iii. Post-monsoon

Corresponding author: Towhida Rashid

Email: towhida_rashid@yahoo.com

DOI: https://doi.org/10.3329/dujees.v9i2.55085
(October and November), iv. Winter (December to February). Pre-monsoon months are typically hot and moderately humid; monsoon months are hot and extremely humid; post-monsoon months are relatively cool and dry, but the winter months are cool and dry.

The average temperature of the country ranges from $23.9{ }^{\circ} \mathrm{C}$ to $31.1{ }^{\circ} \mathrm{C}$ during summer and $7.2{ }^{\circ} \mathrm{C}$ to $12.8{ }^{\circ} \mathrm{C}$ during winter (Shahid, 2010). During summer, temperatures range between 38 and $41^{\circ} \mathrm{C}$ with April being the hottest month. In contrast, January is the coldest month. In winter, average temperature of the country is 16 to $20^{\circ} \mathrm{C}$ during the day and around $10{ }^{\circ} \mathrm{C}$ at night. In pre-monsoon the direction of temperature changes is oriented in southwest to northeast with the cooler zone being the northeast and the warmer zone being the southwest. In winter the temperature gradient is oriented in south to north direction where the northern part is $5{ }^{\circ} \mathrm{C}$ cooler than the southern part of the country (Agrawala et al., 2003).

Heavy rainfall is one of the most relevant characteristics of the climate of Bangladesh. In Bangladesh, the annual rainfall differs from place to place, $1400 \mathrm{~mm}$ in the west to more than $4400 \mathrm{~mm}$ in the east. An exception has been found in the western region of Rajshahi, which is relatively dry and the annual rainfall is about $1600 \mathrm{~mm}$. At least $2000 \mathrm{~mm}$ of rainfall is received in most parts of the country per year. The gradient of rainfall is almost seven $\mathrm{mm} / \mathrm{km}$ 
from west to east of the country. Additional uplifting effect of the Meghalaya plateau is responsible for heavier rainfall in the northeast. Around $80 \%$ of the total rainfall in Bangladesh occurs during the monsoon which is caused by weak tropical depressions that are brought from the Bay of Bengal into Bangladesh by the wet monsoon winds.

Climate change studies may be performed from different aspects such as causes and effects of global warming, variations of temperatures and rainfall, and the earth atmosphere system. Currently some of the climatic parameters and their potential future changes are evaluated in an ensemble of the $5^{\text {th }}$ Phase of Coupled Model Inter-comparison Project. Though the Coupled Model Inter-comparison Project Phase 6 (CMIP6) is the most current and extensive of the CMIPs, because of the availability of data the Coupled Model Inter-comparison Project Phase 5 (CMIP5) has been used more widely till now. CMIP5 is a widely used standard experimental protocol for analyzing the output of coupled atmosphere-ocean general circulation models (AOGCMs). The CMIP5 is coordinated by the World Climate Research Program (WCRP) and has produced a multi-model dataset designed to develop our knowledge of climate, its variability and changes through the application of the models of global climate system (Taylor et al., 2012). The CMIP5 GCMs provide simulations of the long-term climate forced with various scenarios for "radiative forcing", or the energy imbalance of the climate system due to changing greenhouse gas and aerosol concentrations in the atmosphere. These scenarios are called Representative Concentration Pathways (RCPs) (Moss et al., 2010; Van Vuuren et al., 2014).

In this research, an attempt has been taken to analyze the distribution of temperature and rainfall and temperature over Bangladesh using the observed data and CMIP5 models generated data. The long-term trends based on the observational data are compared with those obtained from CMIP5 models data.

\section{DATA, MODEL AND METHODOLOGY}

\section{Data and Model}

This research investigation has been carried based on observational and secondary data collected from different sources. Observational data is given huge importance in the research. Observed data of temperature and rainfall was collected from Bangladesh Meteorological Department (BMD). For this study, data of temperature and rainfall was collected for 34 stations of BMD during the period 1981-2019. The downscaled CMIP5 GCM model data was downloaded from CCCR- (Centre for Climate Change Research) FTP Server (ftp://cccr.tropmet.res.in/FTPServer/NEXINDOUS_D ata/) which are regional data portals for CORDEX (Coordinated Regional Downscaling Experiment) South Asia. This dataset is also known as NEX-GDDP India. The format of the dataset is NetCDF and the spatial resolution of the dataset downloaded from CCCR is 0.25 degrees ( $25 \mathrm{~km}$ x $25 \mathrm{~km})$.

Based on the same ensemble member from the models available at CORDEX for South Asia first 3 models are selected for this study. All the GCM runs for the ensemble member r1ilp1, where, $r$ is realization, $i$ is initialization and $\mathrm{p}$ is parameterization. So, the initial state, initial condition and model physics are the same for all these models. These 3 models are: (i) MPI-ESMLR (ii) MPI-ESM-MR and (iii) NorESM1-M.

\section{Methodology}

This study was conducted on 34 meteorological stations in Bangladesh. These 34 stations were divided into six regions (Table 1).

Table 1: Sub-divisions of the Study Area Along with BMD Stations in the Region

\begin{tabular}{|c|c|c|c|c|c|}
\hline \multirow[t]{2}{*}{ Region } & \multicolumn{2}{|c|}{ Latitude } & \multicolumn{2}{|c|}{ Longitude } & \multirow[t]{2}{*}{ BMD Stations in the Region } \\
\hline & From & To & From & To & \\
\hline Northwest (A) & $24.5^{\circ} \mathrm{N}$ & $26.7^{\circ} \mathrm{N}$ & $88.0^{\circ} \mathrm{E}$ & $90.0^{\circ} \mathrm{E}$ & Bogra, Dinajpur, Rangpur, Syedpur \\
\hline Northeast (B) & $24.0^{\circ} \mathrm{N}$ & $25.25^{\circ} \mathrm{N}$ & $90.0^{\circ} \mathrm{E}$ & $92.60^{\circ} \mathrm{E}$ & Mymensingh, Srimangal, Sylhet \\
\hline $\begin{array}{l}\text { West Central } \\
\text { (C) }\end{array}$ & $23.0^{\circ} \mathrm{N}$ & $24.5^{\circ} \mathrm{N}$ & $88.1^{\circ} \mathrm{E}$ & $90.0^{\circ} \mathrm{E}$ & Chuadanga, Faridpur, Ishurdi, Jessore, Rajshahi, Tangail \\
\hline $\begin{array}{l}\text { East Central } \\
\text { (D) }\end{array}$ & $23.0^{\circ} \mathrm{N}$ & $24.0^{\circ} \mathrm{N}$ & $90.0^{\circ} \mathrm{E}$ & $91.35^{\circ} \mathrm{E}$ & Chandpur, Comilla, Dhaka, Madaripur \\
\hline Southwest (E) & $21.5^{\circ} \mathrm{N}$ & $23.0^{\circ} \mathrm{N}$ & $88.75^{\circ} \mathrm{E}$ & $91.35^{\circ} \mathrm{E}$ & $\begin{array}{c}\text { Barisal, Bhola, Hatiya, Khepupara, Maijdee court, Mongla, } \\
\text { Khulna, Patuakhali, Satkhira }\end{array}$ \\
\hline Southeast (F) & $20.5^{\circ} \mathrm{N}$ & $23.75^{\circ} \mathrm{N}$ & $91.35^{\circ} \mathrm{E}$ & $92.75^{\circ} \mathrm{E}$ & $\begin{array}{c}\text { Chittagong (AP), Cox's Bazar, Feni, Kutubdia, Rangamati, } \\
\text { Sandwip, Sitakunda, Teknaf }\end{array}$ \\
\hline
\end{tabular}


In the analysis of historical period monthly, seasonal and annual model averages and trends were compared with observed averages and trends for temperature and rainfall during the same period of 1981-2019, as consistence observation were available during this period

The trends of the model outputs and observed data were compared for evaluating the specific model status. The evaluation of the model status was done on the basis of the differences between model outputs and observed data.

The following equation (1) was used for temperature and equation (2) was used for rainfall trends difference calculation-

Temperature trends difference

$\left({ }^{\circ} \mathrm{C}\right)=\mathrm{Pi}-\mathrm{Oi}$

Rainfall trends difference

$(\%)=\frac{\mathrm{Pi}-\mathrm{Oi}}{|\mathrm{Oi}|} * 100$

Where, Pi and Oi are the simulation and observed data, respectively.

For temperature the following criteria has been followed for evaluating model status-

Table 2: Criteria for Evaluating Model Status for Temperature

\begin{tabular}{|c|c|}
\hline Model Status & $\begin{array}{c}\text { Differences between Model and } \\
\text { Observed Temperature Trends } \\
\left({ }^{\circ} \mathrm{C} / 10 \text { year }\right)\end{array}$ \\
\hline Similar (S) & \pm 0.4 \\
\hline Overestimation $(\mathrm{O})$ & $>0.4$ \\
\hline Underestimation $(\mathrm{U})$ & $<-0.4$ \\
\hline
\end{tabular}

For rainfall the following criteria has been followed for evaluating model status-

Table 3: Criteria for Evaluating Model Status for Rainfall

\begin{tabular}{|c|c|}
\hline Model Status & $\begin{array}{c}\text { Differences between Model } \\
\text { and Observed Rainfall Trends } \\
(\%)\end{array}$ \\
\hline Similar (S) & \pm 10 \\
\hline Overestimation (O) & $>10$ \\
\hline Underestimation (U) & $<-10$ \\
\hline
\end{tabular}

\section{RESULTS AND ANALYSIS}

\section{Historical Behavior of Rainfall of Bangladesh}

\section{Rainfall Pattern of Bangladesh}

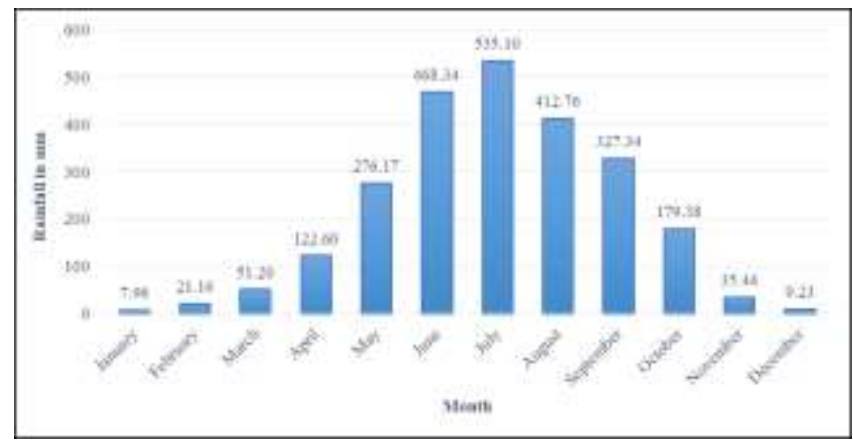

Figure 1: Monthly Mean Rainfall Pattern of Bangladesh according to BMD data during 1981-2019

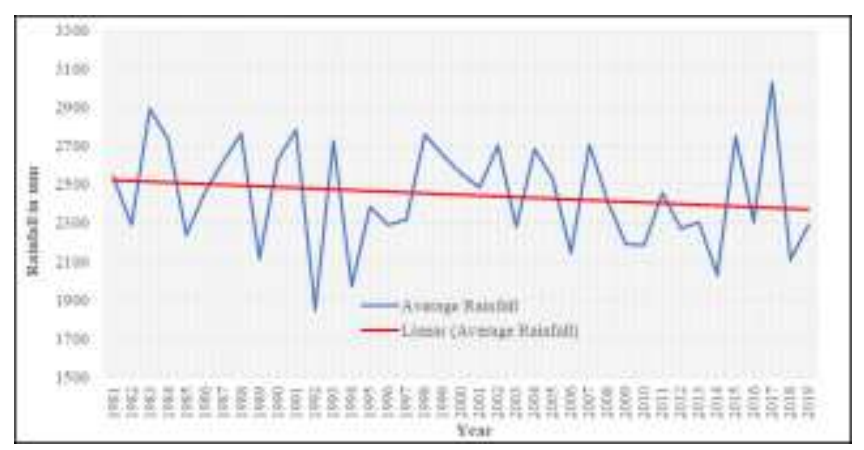

Figure 2: Annual Mean Rainfall Ppattern of Bangladesh According to BMD data during 1981-2019

From the monthly mean rainfall $(\mathrm{mm})$ of 34 observatories of BMD during the period of 1981-2019 (Figure 1) it has been found that rainfalls are higher in the monsoon months and highest in July. But the rainfalls are lower during the winter months and it is the lowest in January. Average monthly rainfall during July is around $535 \mathrm{~mm}$ where in January the average monthly amount is only $7.96 \mathrm{~mm}$.

Figure 2 shows a decreasing trend of yearly mean rainfall. According to BMD data from 1981-2019 rainfall is decreasing almost every year. The annual rainfall of Bangladesh is decreasing at a rate of -3.97 $\mathrm{mm} /$ year during the time period 1981-2019. From this analysis the average annual rainfall of Bangladesh is found to be $2447 \mathrm{~mm}$.

\section{Multi-model Ensemble Monthly, Seasonal and Annual Rainfall over Bangladesh}

Model average annual rainfall during 1981-2019 over Bangladesh was $2287.9 \mathrm{~mm}$ and its trend was $41.6 \mathrm{~mm} / 10 \mathrm{yr}$, which was below the station average 
during the same period. The station average during 1981-2019 was $2446.7 \mathrm{~mm}$ and its trend was -39.7 $\mathrm{mm} / 10 \mathrm{yr}$. The monthly and seasonal variation of multi-model ensemble rainfall over Bangladesh is depicted in the figure (Figure 3).

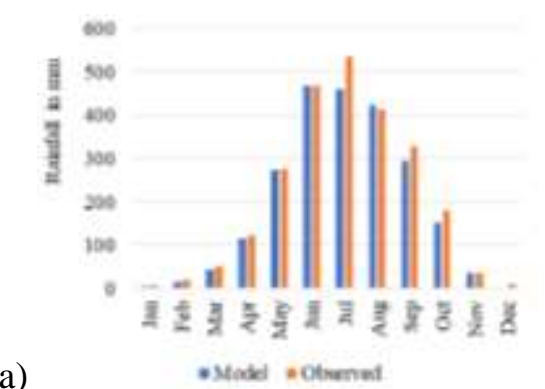

(a)

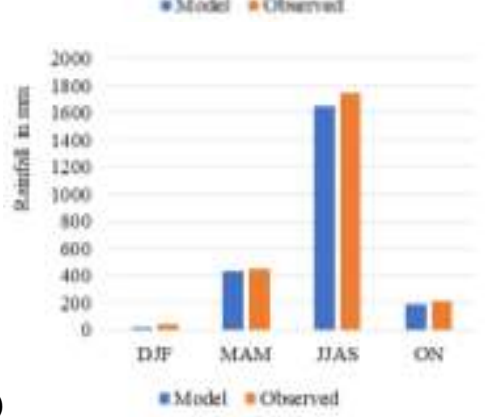

Figure 3: Multi-model Ensemble Variation of (a) Monthly Average and (b) Seasonal Average Rrainfall over Bangladesh

The trends of rainfall over Bangladesh for both multi-model ensemble and observation during 19812019 are given below-
Table 4: Comparison of Multi-model Ensemble and Observed Trends of Rainfall over Bangladesh during 19812019

\begin{tabular}{|c|c|c|c|}
\hline \multirow{2}{*}{ Month } & \multicolumn{2}{|c|}{ Trends (mm/10 year) during P2 } & Model status \\
\cline { 2 - 4 } & Model & Observed & $\mathrm{O} / \mathrm{U} / \mathrm{S}$ \\
\hline January & -1.23 & -1.99 & $\mathrm{O}$ \\
\hline February & -0.47 & -1.36 & $\mathrm{O}$ \\
\hline March & -9.87 & -5.93 & $\mathrm{U}$ \\
\hline April & -14.30 & -16.53 & $\mathrm{O}$ \\
\hline May & -18.87 & -2.22 & $\mathrm{U}$ \\
\hline June & -13.51 & -8.62 & $\mathrm{U}$ \\
\hline July & +15.73 & +9.91 & $\mathrm{O}$ \\
\hline August & +13.27 & -8.83 & $\mathrm{O}$ \\
\hline September & +28.57 & -9.05 & $\mathrm{O}$ \\
\hline October & +1.28 & +11.86 & $\mathrm{U}$ \\
\hline November & +1.88 & -5.64 & $\mathrm{O}$ \\
\hline December & -1.21 & -1.30 & $\mathrm{~S}$ \\
\hline DJF & -2.40 & -6.46 & $\mathrm{O}$ \\
\hline MAM & -40.22 & -24.69 & $\mathrm{U}$ \\
\hline JJAS & +27.39 & -16.59 & $\mathrm{O}$ \\
\hline ON & -0.89 & +5.09 & $\mathrm{U}$ \\
\hline Annual & -41.60 & -39.77 & $\mathrm{~S}$ \\
\hline
\end{tabular}

Table 4 compares the multi-model ensemble monthly, seasonal and annual trends of rainfall over Bangladesh with observed data. Table shows that the model estimation is over the BMD observation during the monsoon months and the overall annual model status is similar with the observed data.

Based on multi-model ensemble and observation, the rainfall situation of the northeastern part of Bangladesh, considered as the most fertile part for rainfall is given below-

Table 5: Comparison of Multi-model Ensemble and Observed Rainfall over the Northeastern part of Bangladesh during 1981-2019

\begin{tabular}{|c|c|c|c|c|c|}
\hline Month & $\begin{array}{c}\text { Model average } \\
(\mathrm{mm})\end{array}$ & $\begin{array}{c}\text { Observed average } \\
(\mathrm{mm})\end{array}$ & \multicolumn{2}{|c|}{ Trends $(\mathrm{mm} / 10$ year) during 1981-2019 } & Model status \\
\cline { 3 - 6 } & 3.4 & 8.7 & -1.31 & Observed & $\mathrm{O} / \mathrm{U} / \mathrm{S}$ \\
\hline January & 29.9 & 28.7 & -0.15 & +1.68 & $\mathrm{U}$ \\
\hline February & 93.8 & 107.8 & -17.78 & +0.78 & $\mathrm{U}$ \\
\hline March & 259.5 & 256.5 & -27.29 & -27.68 & $\mathrm{~S}$ \\
\hline April & 463.9 & 474.8 & -33.67 & -26.79 & $\mathrm{U}$ \\
\hline May & 613.57 & 508.9 & -28.47 & +10.51 & $\mathrm{U}$ \\
\hline June & 608.8 & 549.0 & +33.57 & -6.77 & $\mathrm{O}$ \\
\hline July & 473.7 & 428.5 & -20.98 & -31.17 & $\mathrm{O}$ \\
\hline August & 352.3 & 414.1 & +32.51 & -57.04 & $\mathrm{O}$ \\
\hline September & 200.6 & 208.9 & -3.61 & +28.32 & $\mathrm{U}$ \\
\hline October & 53.7 & 27.5 & +2.89 & -4.89 & $\mathrm{O}$ \\
\hline November & 2.2 & 11.6 & +0.07 & -7.31 & $\mathrm{O}$ \\
\hline December & 35.5 & 49 & -0.96 & -7.43 & $\mathrm{O}$ \\
\hline DJF & 817.2 & 839.1 & -76.27 & -46.32 & $\mathrm{U}$ \\
\hline MAM & 2048.4 & 1900.5 & +56.87 & -80.53 & $\mathrm{O}$ \\
\hline JJAS & 254.3 & 236.4 & -0.87 & +18.69 & $\mathrm{U}$ \\
\hline ON & & &
\end{tabular}




\begin{tabular}{|c|c|c|}
\hline Annual & 3155.4 & 3025 \\
\hline
\end{tabular}

Table 5 compares the multi-model ensemble monthly, seasonal and annual average and trends of rainfall over the northeastern part of Bangladesh with observed data. Table shows the model estimation is over the BMD observation during the monsoon months and the overall annual model status is also overestimated compared to observed data.

Spatial Distribution of Rainfall of Bangladesh:

The spatial distribution of multi-model ensemble annual mean rainfall of Bangladesh is shown in figure 4. The spatial pattern of rainfall shows highest amount of annual rainfall in the northeastern part of Bangladesh.

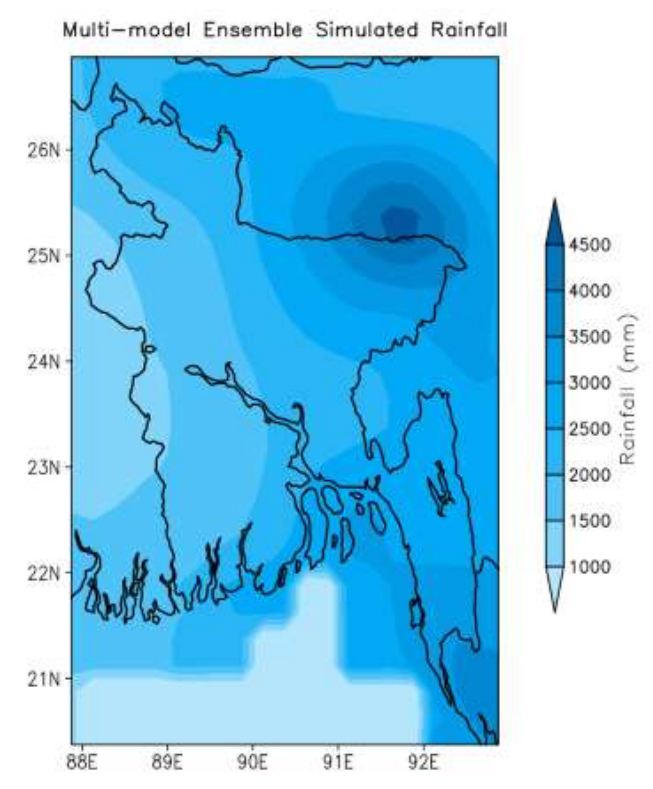

Figure 4: Spatial Distribution of Multi-model Ensemble Simulated Annual Rainfall of Bangladesh

\section{Historical Behavior of Temperature of Bangladesh}

\section{Temperature Pattern of Bangladesh}

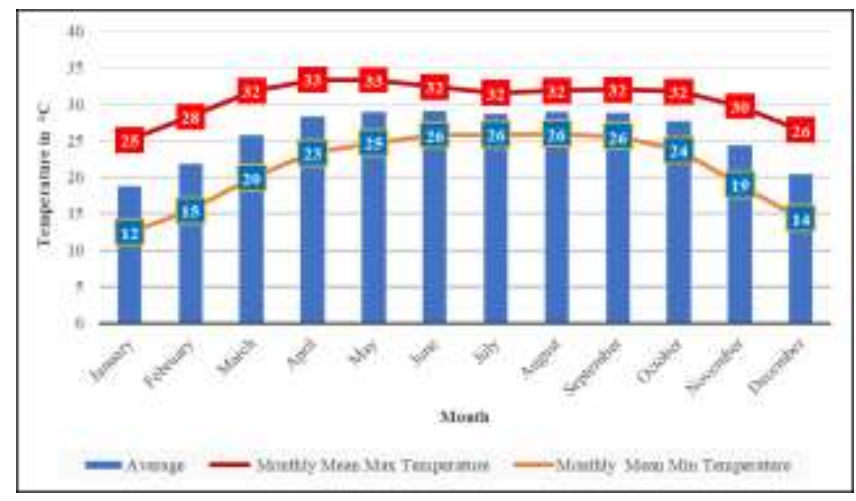

Figure 5: Monthly mean temperature pattern of Bangladesh according to BMD data during 1981-2019

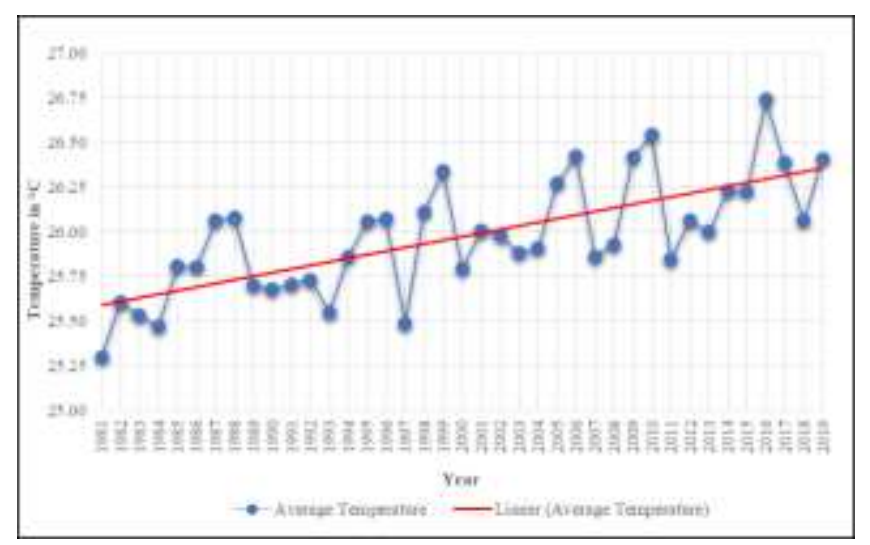

Figure 6: Annual Mean Temperature Pattern of Bangladesh Aaccording to BMD data during 1981-2019

From the monthly mean maximum temperatures $\left({ }^{\circ} \mathrm{C}\right)$ of 34 observatories of BMD during the period of 1981-2019 (Figure 5) it has been found that the magnitudes of mean maximum temperatures in the months of April and May are very close to each other. The temperature has been found to be lowest in January. Figure 5 also depicts that the magnitudes of mean minimum temperatures are higher in the monsoon months of June, July, August and September and they are very close to each other. It is relatively lower in the winter months of December, January and February. January being the lowest.

Figure 6 shows an increasing trend of annual mean temperature. According to BMD data from 1981-2019 temperature is increasing almost every year. The annual temperature of Bangladesh has been increasing at a rate of $+0.02{ }^{\circ} \mathrm{C} /$ year during the time period 1981-2019. From the analysis the mean annual temperature of Bangladesh was found to be $25.96{ }^{\circ} \mathrm{C}$.

The above analysis of the temperature pattern of the study area was conducted on 34 stations of BMD for the period of 1981-2019, however a few stations were established after 1981. These stations are Chuadanga (Established in 1989), Kutubdia (Established in 1985), Mongla (Established in 1989), Sayedpur (Established in 1991) and Tangail (Established in 1987). Therefore, the length of the data collected from these stations has a length less than 30 years. Mean of these few stations has been prepared on the basis of available observed data which were archived at the climate division of BMD. 
Missing data has been excluded from the analysis. It is similar in case for rainfall pattern analysis of the study area.

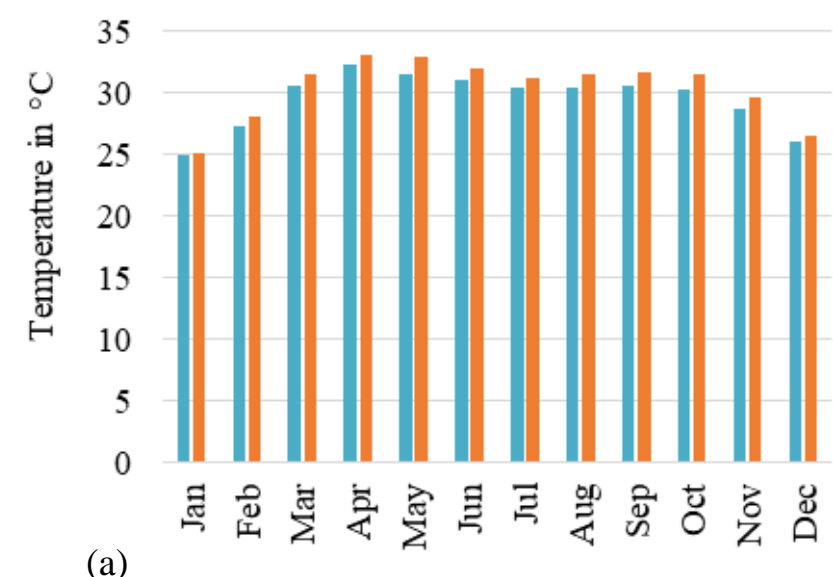

(a)

\section{nodel nObserved}

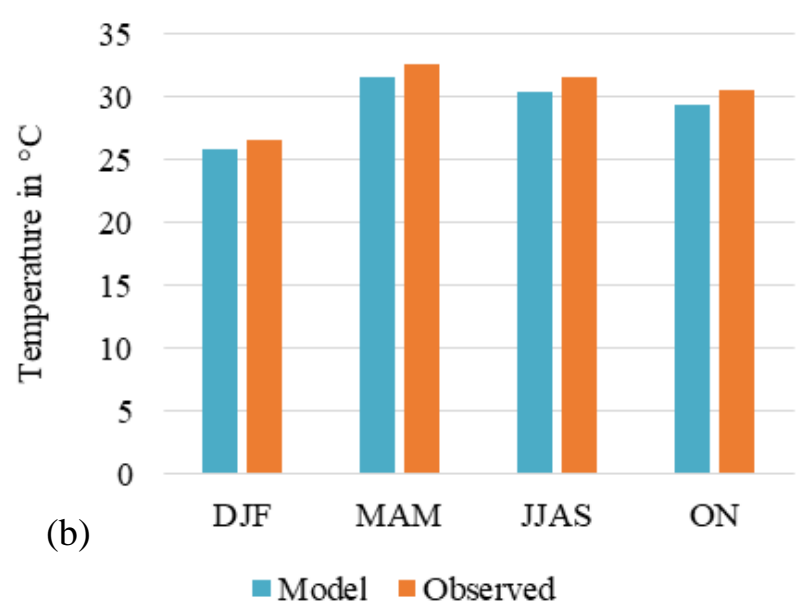

Figure 7: Multi-model Ensemble Variation of (a) Monthly Average and (b) Seasonal Average Maximum Temperature over Bangladesh

\section{Multi-model Ensemble Monthly, Seasonal and Annual Maximum Temperature over Bangladesh}

Model average annual maximum temperature during 1981-2019 over Bangladesh was $29.5^{\circ} \mathrm{C}$ and its trend was $+0.19^{\circ} \mathrm{C} / 10 \mathrm{yr}$, which was below the station average during the same period. The station average during 1981-2019 was $30.5^{\circ} \mathrm{C}$ and its trend was +0.26 ${ }^{\circ} \mathrm{C} / 10 \mathrm{yr}$. The monthly and seasonal variation of multimodel ensemble maximum temperature over Bangladesh is depicted in the figure (Figure 7).

The trends of maximum temperature over Bangladesh for both multi-model ensemble and observation during 1981-2019 are given below-

Table 6: Comparison of Multi-model Ensemble and Observed Trends of Maximum Temperature over Bangladesh

\begin{tabular}{|c|c|c|c|}
\hline \multirow{2}{*}{ Month } & \multicolumn{2}{|c|}{$\begin{array}{c}\text { Trends }\left({ }^{\circ} \mathrm{C} / 10 \text { year }\right) \text { during } \\
\text { 1981-2019 }\end{array}$} & $\begin{array}{c}\text { Model } \\
\text { status }\end{array}$ \\
\cline { 2 - 4 } & Model & Observed & O/U/S \\
\hline January & +0.47 & -0.06 & $\mathrm{O}$ \\
\hline February & +0.30 & +0.37 & $\mathrm{~S}$ \\
\hline March & +0.33 & +0.24 & $\mathrm{~S}$ \\
\hline April & +0.32 & +0.25 & $\mathrm{~S}$ \\
\hline May & +0.25 & +0.35 & $\mathrm{~S}$ \\
\hline June & +0.08 & +0.42 & $\mathrm{~S}$ \\
\hline July & +0.21 & +0.36 & $\mathrm{~S}$ \\
\hline August & +0.12 & +0.37 & $\mathrm{~S}$ \\
\hline September & +0.15 & +0.41 & $\mathrm{~S}$ \\
\hline October & +0.08 & +0.17 & $\mathrm{~S}$ \\
\hline November & +0.09 & +0.22 & $\mathrm{~S}$ \\
\hline December & -0.46 & -0.03 & $\mathrm{U}$ \\
\hline DJF & +0.15 & +0.10 & $\mathrm{~S}$ \\
\hline MAM & +0.26 & +0.28 & $\mathrm{~S}$ \\
\hline JJAS & +0.15 & +0.39 & $\mathrm{~S}$ \\
\hline ON & +0.08 & +0.19 & $\mathrm{~S}$ \\
\hline Annual & +0.19 & +0.26 & $\mathrm{~S}$ \\
\hline
\end{tabular}

Table 6 compares the multi-model ensemble monthly, seasonal and annual trends of maximum temperature over Bangladesh with observed data. Table shows the overall annual model status is similar to observed data.

Based on multi-model ensemble and observation, the maximum temperature situation of the west-central part of Bangladesh, considered as the most important part for maximum temperature is given below-

Table 7: Comparison of Multi-model Ensemble and Observed Maximum Temperature Over the West-central Part of Bangladesh During 1981-2019

\begin{tabular}{|c|c|c|c|c|c|}
\hline \multirow{2}{*}{ Month } & \multirow{2}{*}{ Model average $\left({ }^{\circ} \mathrm{C}\right)$} & \multirow{2}{*}{ Observed average $\left({ }^{\circ} \mathrm{C}\right)$} & \multicolumn{2}{|c|}{ Trends $\left(\left({ }^{\circ} \mathrm{C}\right) / 10\right.$ year $)$ during } & Model status \\
\cline { 4 - 6 } & & & Model & Observed & $\mathrm{O} / \mathrm{U} / \mathrm{S}$ \\
\hline January & 26.1 & 24.7 & +0.19 & -0.70 & $\mathrm{O}$ \\
\hline February & 28.0 & 28.2 & +0.26 & +0.10 & $\mathrm{~S}$ \\
\hline March & 33.2 & 32.8 & +0.30 & +0.02 & $\mathrm{~S}$ \\
\hline
\end{tabular}




\begin{tabular}{|c|c|c|c|c|c|}
\hline \multirow{2}{*}{ Month } & \multirow{2}{*}{ Model average $\left({ }^{\circ} \mathrm{C}\right)$} & \multirow{2}{*}{ Observed average $\left({ }^{\circ} \mathrm{C}\right)$} & \multicolumn{2}{|c|}{ Trends $\left(\left({ }^{\circ} \mathrm{C}\right) / 10\right.$ year $)$ during } & \multirow{2}{*}{ Model status } \\
\cline { 4 - 6 } & & & Model & Observed & O/U/S \\
\hline April & 36.7 & 35.2 & +0.41 & -0.04 & $\mathrm{O}$ \\
\hline May & 35.6 & 34.5 & +0.31 & +0.12 & $\mathrm{~S}$ \\
\hline June & 33.7 & 33 & +0.28 & +0.28 & $\mathrm{~S}$ \\
\hline July & 32.3 & 32.2 & +0.09 & +0.40 & $\mathrm{~S}$ \\
\hline August & 32.2 & 32.3 & +0.09 & +0.62 & $\mathrm{U}$ \\
\hline September & 32.5 & 32.3 & +0.05 & +0.25 & $\mathrm{~S}$ \\
\hline October & 32.2 & 31.6 & +0.07 & -0.40 & $\mathrm{O}$ \\
\hline November & 30.1 & 29.5 & +0.03 & +0.27 & $\mathrm{~S}$ \\
\hline December & 27.1 & 25.9 & -0.08 & +0.20 & $\mathrm{~S}$ \\
\hline DJF & 27.1 & 26.3 & +0.12 & -0.14 & $\mathrm{~S}$ \\
\hline MAM & 35.2 & 34.2 & +0.36 & +0.04 & $\mathrm{O}$ \\
\hline JJAS & 32.7 & 32.5 & +0.13 & +0.39 & $\mathrm{~S}$ \\
\hline ON & 31.2 & 30.6 & +0.05 & -0.07 & $\mathrm{~S}$ \\
\hline Annual & 31.3 & 30.7 & +0.15 & +0.07 & $\mathrm{~S}$ \\
\hline
\end{tabular}

Table 7 compares the multi-model ensemble monthly, seasonal and annual average and trends of maximum temperature over the west-central part of Bangladesh with observed data. Table shows the overall annual model status is similar compared to observed data.

\section{Spatial Distribution of Maximum Temperature of Bangladesh}

The spatial distribution of multi-model ensemble annual mean maximum temperature of Bangladesh is shown in figure 8 . The spatial pattern of maximum temperature shows the highest annual temperature in the western part of Bangladesh.

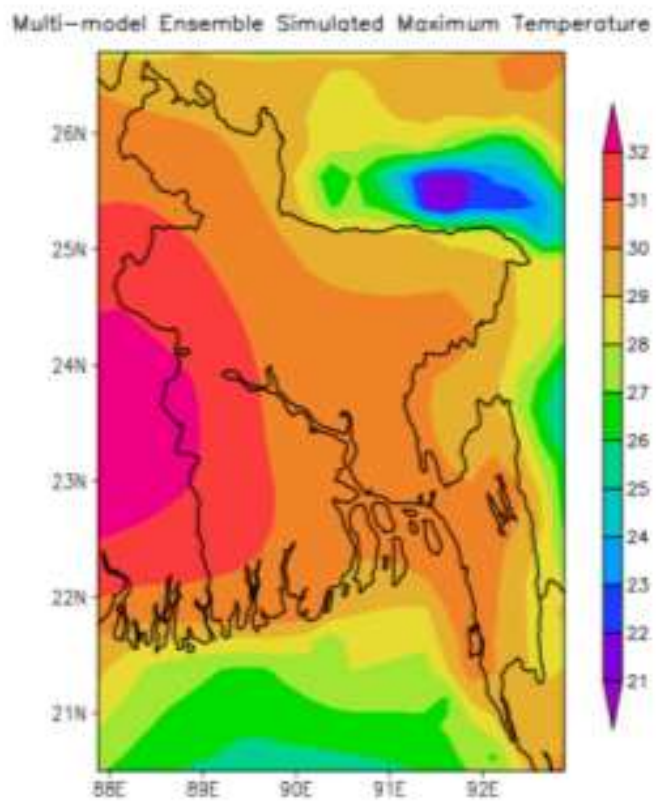

Figure 8: Spatial Distribution of Multi-model Ensemble Simulated Maximum Temperature
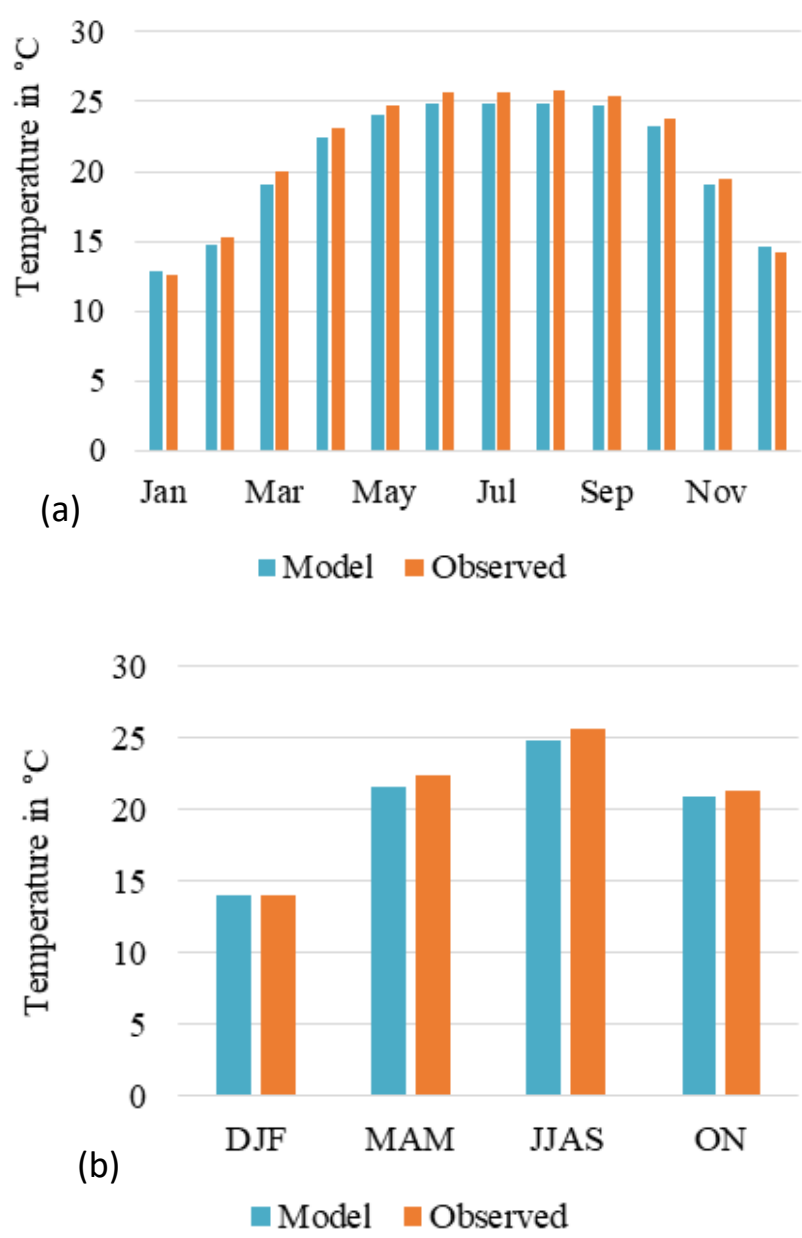
Figure 9: Multi-model Ensemble Variation of (a) Monthly Average and (b) Seasonal Average Minimum Temperature over Bangladesh

\section{Multi-model Ensemble Monthly, Seasonal and Annual Minimum Temperature over Bangladesh}

Model average annual minimum temperature during 1981-2019 over Bangladesh was $20.8{ }^{\circ} \mathrm{C}$ and its trend was $+0.18{ }^{\circ} \mathrm{C} / 10 \mathrm{yr}$, which was below the station average during the same period. The station average during $1981-2019$ was $21.3{ }^{\circ} \mathrm{C}$ and its trend was $+0.15{ }^{\circ} \mathrm{C} / 10 \mathrm{yr}$. The monthly and seasonal variation of multi-model ensemble minimum temperature over Bangladesh is depicted in the figure (Figure 9).

The trends of minimum temperature over Bangladesh for both multi-model ensemble and observation during 1981-2019 are given below-

Table 8 compares the multi-model ensemble monthly, seasonal and annual trends of minimum temperature over Bangladesh with observed data. Table shows the overall annual model status is similar compared to observed data.
Table 8: Comparison of Multi-model Ensemble and Observed Trends of Minimum Temperature over Bangladesh

\begin{tabular}{|c|c|c|c|}
\hline \multirow{2}{*}{ Month } & \multicolumn{2}{|c|}{$\begin{array}{c}\text { Trends }\left({ }^{\circ} \mathrm{C} / 10 \text { year) during }\right. \\
\text { Model }\end{array}$} & $\begin{array}{c}\text { Model } \\
\text { status }\end{array}$ \\
\cline { 2 - 4 } & +0.29 & -0.13 & $\mathrm{O} / \mathrm{U} / \mathrm{S}$ \\
\hline January & +0.25 & +0.44 & $\mathrm{~S}$ \\
\hline February & +0.25 & +0.22 & $\mathrm{~S}$ \\
\hline March & +0.36 & +0.26 & $\mathrm{~S}$ \\
\hline April & +0.30 & +0.24 & $\mathrm{~S}$ \\
\hline May & +0.17 & +0.11 & $\mathrm{~S}$ \\
\hline June & +0.10 & +0.25 & $\mathrm{~S}$ \\
\hline July & +0.15 & +0.17 & $\mathrm{~S}$ \\
\hline August & +0.14 & +0.10 & $\mathrm{~S}$ \\
\hline September & +0.14 & +0.27 & $\mathrm{~S}$ \\
\hline October & +0.28 & +0.24 & $\mathrm{~S}$ \\
\hline November & +0.15 & +0.17 & $\mathrm{~S}$ \\
\hline December & +0.23 & +0.07 & $\mathrm{~S}$ \\
\hline DJF & +0.30 & +0.21 & $\mathrm{~S}$ \\
\hline MAM & +0.16 & +0.19 & $\mathrm{~S}$ \\
\hline JJAS & +0.16 & +0.09 & $\mathrm{~S}$ \\
\hline ON & +0.18 & +0.15 & $\mathrm{~S}$ \\
\hline Annual & & & \\
\hline & & & \\
\hline
\end{tabular}

Based on multi-model ensemble and observation, the minimum temperature situation of the northwestern part of Bangladesh, considered as the most important part for minimum temperature is given below-

Table 9: Comparison of Multi-model Ensemble and Observed Minimum Temperature over the Northwestern part of Bangladesh during 1981-2019

\begin{tabular}{|c|c|c|c|c|c|}
\hline \multirow{2}{*}{ Month } & $\begin{array}{c}\text { Model average } \\
\left({ }^{\circ} \mathrm{C}\right)\end{array}$ & $\begin{array}{c}\text { Observed average } \\
\left({ }^{\circ} \mathrm{C}\right)\end{array}$ & \multicolumn{2}{|c|}{ Trends $\left(\left({ }^{\circ} \mathrm{C}\right) / 10\right.$ year $)$ during 1981-2019 } & $\begin{array}{c}\text { Model status } \\
\text { O/U/S }\end{array}$ \\
\cline { 4 - 5 } & 11.4 & 10.7 & +0.29 & -0.13 & $\mathrm{O}$ \\
\hline January & 13.5 & 13.3 & +0.34 & +0.69 & $\mathrm{~S}$ \\
\hline February & 16.8 & 17.5 & +0.28 & +0.56 & $\mathrm{~S}$ \\
\hline March & 21.5 & 21.4 & +0.41 & +0.40 & $\mathrm{~S}$ \\
\hline April & 23.6 & 23.4 & +0.35 & +0.49 & $\mathrm{~S}$ \\
\hline May & 25.2 & 25.4 & +0.16 & +0.28 & $\mathrm{~S}$ \\
\hline June & 25.7 & 26.1 & +0.09 & +0.53 & $\mathrm{U}$ \\
\hline July & 25.9 & 26.2 & +0.10 & +0.19 & $\mathrm{~S}$ \\
\hline August & 25.4 & 25.3 & +0.15 & +0.25 & $\mathrm{~S}$ \\
\hline September & 22.9 & 22.7 & +0.21 & +0.23 & $\mathrm{~S}$ \\
\hline October & 16.7 & 17.3 & +0.15 & +0.69 & $\mathrm{U}$ \\
\hline November & 13.5 & 13.1 & +0.09 & +0.43 & $\mathrm{~S}$ \\
\hline December & 12.8 & 12.4 & +0.24 & +0.35 & $\mathrm{~S}$ \\
\hline DJF & 20.6 & 20.8 & +0.36 & +0.49 & $\mathrm{~S}$ \\
\hline MAM & 25.6 & 25.8 & +0.13 & +0.32 & $\mathrm{~S}$ \\
\hline JJAS & 19.8 & 20 & +0.12 & +0.46 & $\mathrm{~S}$ \\
\hline ON & 20.7 & 20.7 & +0.20 & +0.41 & $\mathrm{~S}$ \\
\hline Annual & & & & \\
\hline
\end{tabular}


Table 9 compares the multi-model ensemble monthly, seasonal and annual average and trends of minimum temperature over the northwestern part of Bangladesh with observed data. Table shows the overall annual model status is similar compared to observed data.

\section{Spatial Distribution of Minimum Temperature of Bangladesh}

The spatial distribution of multi-model ensemble annual mean minimum temperature of Bangladesh is shown in figure 10. The spatial pattern shows the highest annual minimum temperature in the western and central part of Bangladesh.

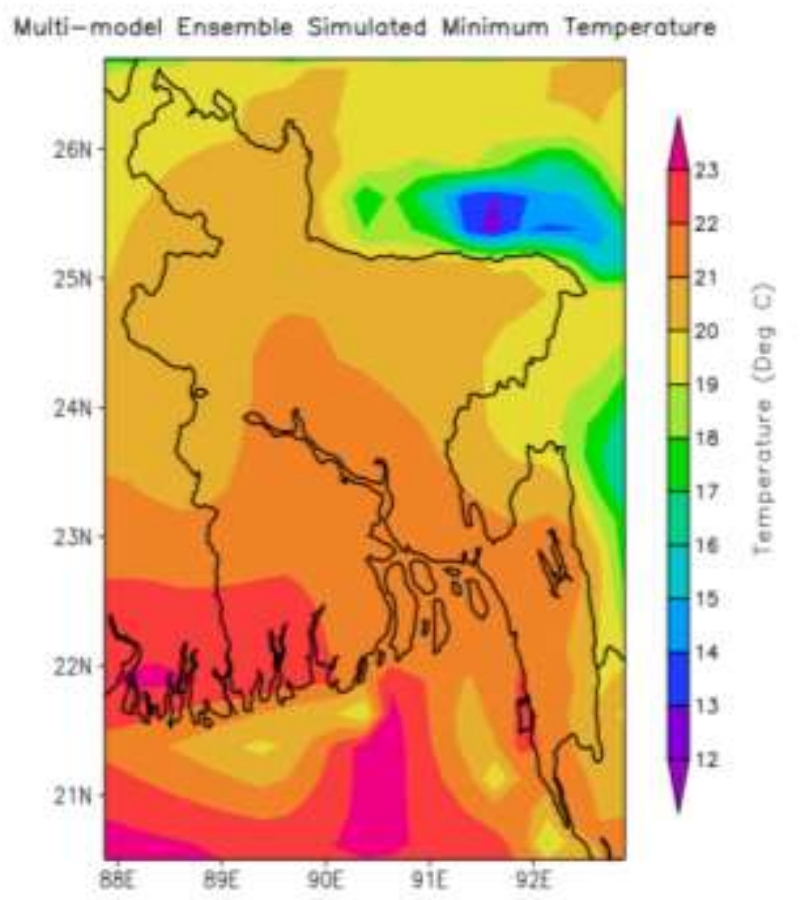

Figure 10: Spatial Distribution of Multi-model Ensemble Simulated Minimum Tmperature of Bangladesh

\section{DISCUSSION AND CONCLUSION}

This study assessed the performance of three GCMs from CMIP5 to reproduce the current climate and analyze the trends of temperature and rainfall in different parts of Bangladesh.

The results mostly show underestimation when compared with the observed data, especially during the monsoon months in terms of rainfall, but for temperature the result is found almost similar between models and observation. Significant increase in mean maximum and minimum temperature and slightly decreasing average areal rainfall over Bangladesh has been observed during the period 1981-2019. Spatial pattern shows that annual rainfall has increased in the western part of Bangladesh gradually.

The results of this study indicate that the northwestern part of Bangladesh is highly vulnerable to climate change due to the large increase in the annual mean temperature. The enhanced future warming is likely to severely impact the irrigation patterns (Chaturvedi et al., 2014) and irregular rainfall may cause extreme summer flash floods over this region in the future.

This study has established a link of trend comparison through observational data and climate models. The results presented in this study should be useful for climate adaptation strategies for the different regions of Bangladesh. In addition, the results of the study can be useful for conducting climatology studies and climate change impact assessment over Bangladesh.

\section{REFERENCES}

Agrawala, S., Ota, T., Ahmed, A.U., Smith, J. and Van Aalst, M. (2003). Development and climate change in Bangladesh: focus on coastal flooding and the Sundarbans, pp. 1-49. Paris: OECD.

Chaturvedi, R.K., Kulkarni, A., Karyakarte, Y., Joshi, J. and Bala, G. (2014). Glacial mass balance changes in the Karakoram and Himalaya based on CMIP5 multimodel climate projections. Climatic Change, 123(2), pp.315-328.

Fung, C.F., Farquharson, F. and Chowdhury, J. (2006). Exploring the impacts of climate change on water resources-regional impacts at a regional scale: Bangladesh. IAHS PUBLICATION, 308, p.389.

Inter-Governmental Panel on Climate Change (IPCC). (2007). Summary for Policymakers. In Climate Change 2007: The Physical Science Basis; Contribution of Working Group I to the Fourth Assessment Report of IPCC; Cambridge University Press: Cambridge, UK; New York, NY, USA.

Inter-Governmental Panel on Climate Change (IPCC). (2013). Summary for Policymakers. In Climate Change 2013: The Physical Science Basis; Contribution of Working Group I to the Fifth Assessment Report of IPCC; Cambridge University Press: Cambridge, UK; New York, NY, USA.

Karim, Z., Hussain, S.G. and Ahmed, A.U. (1999). Climate change vulnerability of crop agriculture. In 
Vulnerability and adaptation to climate change for Bangladesh, pp. 39-54. Springer, Dordrecht.

Moss, R.H., Edmonds, J.A., Hibbard, K.A., Manning, M.R., Rose, S.K., Van Vuuren, D.P., Carter, T.R., Emori, S., Kainuma, M., Kram, T. and Meehl, G.A. (2010). The next generation of scenarios for climate change research and assessment. Nature, 463(7282), pp.747-756.

Shahid, S. (2009). Probable impacts of climate change on public health in Bangladesh. Asia Pacific Journal of Public Health, 22(3), pp.310-319.

Shahid, S. (2010). Recent trends in the climate of Bangladesh. Climate Research, 42(3), pp.185-193.
Taylor, K.E., Stouffer, R.J. and Meehl, G.A. (2012). An overview of CMIP5 and the experiment design. Bulletin of the American Meteorological Society, 93(4), pp.485-498.

Van Vuuren, D.P., Kriegler, E., O’Neill, B.C., Ebi, K.L., Riahi, K., Carter, T.R., Edmonds, J., Hallegatte, S., Kram, T., Mathur, R. and Winkler, H. (2014). A new scenario framework for climate change research: scenario matrix architecture. Climatic Change, 122(3), pp.373-386 